\title{
6
}

\section{Fungi, Bacteria, and Other Biopollutants}

\author{
Aino Nevalainen, * Martin Täubel and Anne \\ Hyvärinen
}

\section{Definitions}

Biological particles are a diverse group of particulate matter present almost everywhere, in the atmospheric environment, soils and waters, and in indoor environments. Common to all of these particles is the biological origin: microbial, plant, or animal sources. Examples of microbial particles are moulds and yeasts, bacteria, and viruses; particles of plant origin are pollen and algae, and various particles also originate from animals (including humans). Biological particles may be viable or non-living, dead material. The health effects and biological characteristics of these particles are also diverse; pollen and microbial spores being essential parts of the organism's multiplication system, some viruses and bacteria having dramatic potential as pathogenic organisms, and some components representing other types of health-related biological activity, such as plant and fungal allergens and bacterial endotoxin.

Biological particles are present in the atmosphere, and assessments of their concentrations have been made for a long time. Using culture-based sampling and analysis methods for fungi and bacteria, and direct counting methods for pollen, their occurrence has been monitored and their transport across regions and even continents documented. However, only the recent development of DNA based methods has really made it possible to comprehensively characterize the atmospheric microbiomes and their behavior. Thus, the importance of biological particles in the atmosphere has only been possible to recognize during the last decades. Research has suggested that they

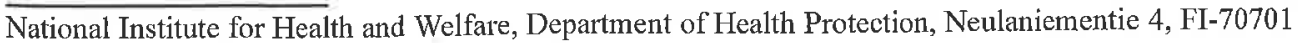
Kuopio, Finland.

* Corresponding author: aino.nevalainen@thl.fi
} 
can have a substantial influence on atmospheric chemistry, cloud development, and precipitation (Andreae and Rosenfeld 2008; Després et al. 2012).

The size range of airborne biological particles extends from nanometers, the size of cell fragments and viruses, to around $100 \mu \mathrm{m}$ and more (Després et al. 2012; Reponen et al. 2011), the size of some pollen, plant debris, and aggregates of biological material. Part of the biological particles occurs as individual particles in the air. Examples of such particles are pollen and fungal spores. Traces of plant and their allergen material may also be carried by other particles. Fungal and bacterial spores may occur as individual particles but also as aggregates or they may be carriers of microbial products, such as mycotoxins or bacterial equivalents. Fungal and bacterial material may also be present in air as smaller particles than the original cells (Górny et al. 2002; Green et al. 2006).

Fungi and bacteria may occur as viable particles, which means that they are metabolically active and able to reproduce once the environmental conditions for nutrients, moisture, and temperature are good enough, or they may occur as nonviable (dead) particles, or in a dormant state which is something in between these statuses. Even dead or dormant cells may carry biologically active constituents, such as endotoxin, glucan, allergens, or toxins; among the characteristics that have importance to health, only the ability to cause infections is known to be bound to the viability of the causal organism.

\section{Sources, description, and occurrence of biological particles}

\section{Fungi-Introduction}

Fungi are eukaryotic organisms that form their own biological Kingdom, having features both from micro-organisms (bacteria, viruses, protozoa) and those of plants. Fungi are classified in groups based on their method of growth and multiplication. Yeasts are a group of single cell fungi that differ from other fungi; they multiply by dividing cells only. Filamentous fungi form filaments (hyphae) that aggregate to form fungal mycelium. This can often be seen by naked eye, usually known as mold or mildew. Fungal mycelium can transport nutrients and water and thus allow the growth in sites where these supplies are scarce. Mycelium also develops reproductional structures and releases spores that may travel long distances to find new sites for growth. In general, fungal spores are present everywhere, and their germination and growth are regulated by the environment, i.e., availability of nutrients and water, adequate temperature, and a proper surface.

Fungi contribute about one quarter of the total biomass in the planet. Their basic ecological role is to aerobically decay organic material in nature, which is a crucial basis for the nutrient cycle, and to provide plants the necessary nutrients for their growth. Fungi consist of different groups: yeasts, molds and mildews, commonly known as microfungi, and mushrooms and other fungi. Microfungi are common both in outdoor and indoor environments. Fungal spores and also other fungal material, such as hyphal fragments, are easily released into the air. Their importance to mankind is both potentially harmful and beneficial. They may act as human pathogens or allergens, plant pathogens destroying crops and forests, and damage buildings as do many molds and rot fungi. However, fun of enzymes, antibiotics and beer, milk products, and ba

Some structural compc active agents and are th Beta-(1->3)-D-glucans (Dc potential agents contributing inflammatory potential (Do respiratory allergies simila et al. 2007). Fungi that con Alternaria, and Fusarium ergosterol, which is the $\mathrm{cc}$ in assessment of total fun exposures is poorly knowr

On top of intracellular for producing extracellul aims to provide proteins growth, secondary metabc (microbial volatile organic as mycotoxins. MVOC cc aldehydes and their mixt These volatile compound: effects (Korpi et al. 2009', mycotoxins, together wit agents with possible healtl

Traditional method: microscopy or on their $\mathrm{cu}$ identification by microsc and reproductive structur be cultivated on the gives Examples of common fus

\section{Sources and occurr}

Essential sources of env surface and substrate for Therefore, plants and so The more vegetation, $\mathrm{tr}$ do most of the decaying and coldest areas of th biological action in suck of reproducing fungi.

All waters contain sites for fungi as are all fragments, and other pa 
ud development, and ).

anometers, the size of et al. 2012; Reponen if biological material. air. Examples of such llergen material may y occur as individual jial products, such as $1 \mathrm{may}$ also be present 2; Green et al. 2006). means that they are rental conditions for ' may occur as nonng in between these active constituents, acteristics that have in to be bound to the

\section{gical}

11 Kingdom, having and those of plants. and multiplication. gi; they multiply by at aggregate to form $r$ known as mold or ius allow the growth lops reproductional ) find new sites for eir germination and utrients and water,

s planet. Their basic ;, which is a crucial $r$ nutrients for their vildews, commonly zi are common both ungal material, such tance to mankind is hogens or allergens, is as do many molds and rot fungi. However, fungi are also used in biotechnological industries as producers of enzymes, antibiotics and other pharmaceuticals, and in production of cheese, wine, beer, milk products, and baking products.

Some structural components of fungal cells have been identified as biologically active agents and are therefore interesting from the health point of view. Beta-(1 $>3$ )-D-glucans (Douwes 2005) are regular constituents of fungal cells and potential agents contributing to the health effects linked with fungal exposures. They have inflammatory potential (Douwes 2005) but may also provide protective effects against respiratory allergies similarly to bacterial endotoxin (Yossifova et al. 2007; Gehring et al. 2007). Fungi that contain known allergens are, e.g., Cladosporium, Aspergillus, Alternaria, and Fusarium species. Another structural component of fungal cells, ergosterol, which is the common sterol for all fungi, is used as a chemical marker in assessment of total fungal biomass, but its possible role in health risks of fungal exposures is poorly known.

On top of intracellular components of fungal cells, fungi also have great potential for producing extracellular secondary metabolites. As their primary metabolism aims to provide proteins, carbohydrates, nucleic acids, and lipids for their own growth, secondary metabolism produces volatile compounds, also known as MVOC (microbial volatile organic compounds) and non-volatile compounds often designated as mycotoxins. MVOC compounds are typically organic acids, alcohols, esters, and aldehydes and their mixtures are often recognized as odor of mold, earth, or cellar. These volatile compounds are usually not acutely toxic, but they may have irritative effects (Korpi et al. 2009). Instead, the group of non-volatile secondary metabolites, mycotoxins, together with bacterial exotoxins, represent a more potential group of agents with possible health effects, and they are introduced as a separate section below.

Traditional methods of analyzing fungi are largely based on either direct microscopy or on their cultivation on laboratory media and subsequent morphological identification by microscopy. The identification relies upon the characteristic hyphal and reproductive structures of each fungus. With these methods, those fungi that can be cultivated on the given media and growth conditions can be found and quantified. Examples of common fungal genera in outdoor and indoor air are listed in Table 6-1.

\section{Sources and occurrence of fungi}

Essential sources of environmental fungi are all natural environments that provide surface and substrate for their growth, that is organic material and enough moisture. Therefore, plants and soils of the planet are the major sources of all fungal material. The more vegetation, the more organic cycle of nutrients and the more fungi that do most of the decaying work of organic material. However, even the driest deserts and coldest areas of the world have their natural mycobiota although the scarce biological action in such extreme environments means that they are no major sources of reproducing fungi.

All waters contain fungi as well, but they are not nearly as important growth sites for fungi as are all kinds of plants and soils. From these sources, fungal spores, fragments, and other particles end up into the atmosphere where they can travel long 
Table 6-1. Examples of fungal genera commonly occurring in outdoor and indoor environments as detected with culture methods. Many fungal genera, particularly Aspergillus and Penicillium, are represented by a number of different species.

\begin{tabular}{ll}
\hline Acremonium \\
Alternaria \\
Aspergillus \\
Aureobasidium \\
Botrytis \\
Chaetomium \\
Cladosporium \\
Epicoccum \\
Eurotium \\
Exophiala \\
Fusarium \\
Geomyces \\
Geotrichum \\
Mucor \\
Oidiodendron \\
Paecilomyces \\
Penicillium \\
Phialophora \\
Phoma \\
Rhizopus \\
Rhodotorula \\
Scopulariopsis \\
Sporobolomyces \\
Stachybotrys \\
Trichoderma \\
Tritirachium \\
Ulocladium \\
Wallemia \\
\hline
\end{tabular}

distances to the other side of the globe (Smith et al. 2012). Fungal spores are found in atmospheric layers (Polymenakou 2012; Després et al. 2012). Wind, rain, and other weather factors influence their traffic in the same way as that of other atmospheric particles. Concentrations and composition of the mycobiota at a given monitoring site is not stable but have relatively large variation due to geographical, weather, and light conditions (Bowers et al. 2013). Examples of concentrations of cultivable fungi in outdoor air are shown in Table 6-2.

The fungal biomass in the environment that cannot be cultivated under laboratory conditions is greater both quantitatively and qualitatively than the "viable" or "cultivable" fungal material. The ratio of viable and non-viable fungal biomass depends on the environment, i.e., whether the sample has been taken from soil, air, water, house dust, or another source. The fact that only a part of all microbes can be cultivated has been known for long by analyzing fungal content of samples, e.g., by direct microscopy without cultivation. For example, in aerobiological monitoring of pollen and fungal allergens, certain types of spores and fungal groups can be quantified by this way. However, the development of DNA-based methods during the past decades has made a methodological revolution in making it possible to characterize the fungal biomass independently from its viability. The methods for microbial analyses are further discussed later in this chapter.
Table 6-2. Examples of concentra Environment

Outdoor air

Homes in different countries School buildings

Waste collection work

Composting facility

Wood chip handling

Swine confinement buildings

Demolition work of moldy struct

1. Macher et al. 1991, 2. Kuo and 6. Reponen et al. 1992, 7. Pastusz] et al. 1995, 11. Moller-Nielsen et al. 2003, 15. Rautiala et al. 1996.

The estimates of the po mass vary. For example, bic $5-50 \%$ of outdoor particles । in number and mass conce estimated to account for up or suburban locations (Des)

\section{Fungi in indoor envir}

Indoor environments are w] most contacts with airbo environments. This is critir In general, outdoor air is $\mathrm{t}$ environments (Gravesen 19' geography, and the ventilati environment resembles ma indoor environments not onl in the structures and via ve also carried indoors on clot et al. 1989).

On top of the backgr outdoors, there are also int the concentrations and spec Some sources of indoor fur

Normal household act and species. Measured as $\mathrm{T}$ of magnitude was observer door. Increased concentrati fruit and unwashed root $\mathrm{v}$ such concentration peaks addition to yeasts (Lehton 
snvironments as detected um, are represented by a

gal spores are found in . Wind, rain, and other $t$ of other atmospheric at a given monitoring zraphical, weather, and ions of cultivable fungi

ivated under laboratory $r$ than the "viable" or viable fungal biomass :en taken from soil, air, $t$ of all microbes can be ent of samples, e.g., by iological monitoring of groups can be quantified s during the past decades s characterize the fungal microbial analyses are
Table 6-2. Examples of concentrations of viable fungi in various environments.

\begin{tabular}{lcc}
\hline Environment & Concentration CFU m & Reference \\
\hline Outdoor air & $10^{2}-10^{4}$ & $1,2,3$ \\
Homes in different countries & $10^{1}-10^{3}$ & $4,5,6,7$ \\
School buildings & $<10^{1}-10^{3}$ & $8,9,10$ \\
Waste collection work & $<10^{2}-10^{5}$ & 11 \\
Composting facility & $10^{3}-10^{7}$ & 12 \\
Wood chip handling & $10^{3}-10^{7}$ & 13 \\
Swine confinement buildings & $10^{2}-10^{5}$ & 14 \\
Demolition work of moldy structures & $10^{3}-10^{5}$ & 15 \\
\hline
\end{tabular}

1. Macher et al. 1991, 2. Kuo and Li 1994, 3. Ren et al. 1999, 4. Haas et al. 2007, 5. Frankel et al. 2012, 6. Reponen et al. 1992, 7. Pastuszka et al. 2000, 8. Meklin et al. 2002, 9. Gravesen et al. 1983, 10. Levetin et al. 1995, 11. Moller-Nielsen et al. 1997, 12. Durand et al. 2002, 13. Alwis et al. 1999, 14. Rautiala et al. 2003, 15. Rautiala et al. 1996.

The estimates of the portion biological particles represent in atmospheric particle mass vary. For example, biological particles $>0.2 \mu \mathrm{m}$ have been assessed to comprise $5-50 \%$ of outdoor particles (Jaenicke 2005). Fungal spores have been assessed to occur in number and mass concentrations $\sim 10^{4} \mathrm{~m}^{-3}$ and $\sim 1 \mu \mathrm{g} \mathrm{m}^{-3}$, respectively, and are estimated to account for up to $\sim 10 \%$ of organic carbon and $\sim 5 \%$ of PM10 at urban or suburban locations (Després et al. 2012).

\section{Fungi in indoor environments}

Indoor environments are where humans today mostly spend their time, and therefore most contacts with airborne biological particles take place probably in these environments. This is critical from the point of view of health effects assessment. In general, outdoor air is the main source of fungi commonly occurring in indoor environments (Gravesen 1979; Burge 1990). Depending to some extent on the climate, geography, and the ventilation system of the building, normal mycobiota of an indoor environment resembles mainly that of the local outdoor air. Outdoor fungi enter the indoor environments not only through open windows and doors but also through cracks in the structures and via ventilation system as do other outdoor particles. Fungi are also carried indoors on clothing and shoes of occupants, and on fur of pets (Pasanen et al. 1989).

On top of the background concentrations and mycobiota originating from outdoors, there are also intramural sources of fungi that make their contribution to the concentrations and species diversity of indoor air and to the exposures of humans. Some sources of indoor fungi are presented in the following.

Normal household activities have an effect on indoor fungal concentrations and species. Measured as viable fungi, increase of fungal concentrations of orders of magnitude was observed as a result of handling of firewood or opening a cellar door. Increased concentrations were also shown as a result of cleaning and handling fruit and unwashed root vegetables. The major viable fungal genera observed in such concentration peaks were Penicillium, Cladosporium, and Aspergillus, in addition to yeasts (Lehtonen et a1. 1993). Temporary wetting of spots on various 
surfaces where fungal spores have accumulated may also allow the germination and hyphal growth of rapidly growing fungi, creating microcolonies that can produce spores into the indoor air. This phenomenon may only take hours or days (Pasanen et al. 1991). Common sources of indoor fungi are also sites or areas in the building structures where moisture can be accumulated for one reason or another, e.g., by leaks, condensation, flooding, or capillary movement of moisture. Such moisture causes growth of fungi and bacteria, which is recognized as mold with naked eye. Growth of mold on indoor surfaces or in building structures is associated with many health effects (WHO 2009) and considered therefore an undesired phenomenon which acts as a source of fungal particles, volatile metabolites, and toxic substances (Adan and Samson 2011).

It has been discussed whether a wall-to-wall carpet acts as a source or as a sink of indoor fungi. Evidently, both are possible and the phenomenon depends both on the characteristics of the carpet and on the fungal species in question. In an experimental study, Shorter (2012) showed that both PM2.5 and fungal spores were aerosolized from a hard floor more easily than from a carpet surface. Almost no reaerosolization took place from a carpet loaded with low levels of dust, but when higher loading was used, differences in resuspension between fungal spore types were noticed. Small and spherical Penicillium spores were more easily aerosolized than larger Alternaria spores (Shorter 2012).

Microbial diversity in house dust has been characterized in a number of studies using cultivation methods, and in a few studies using non-culturable methods. Especially studies using culture-independent methods have shown that in indoor environments, there are various sources and reservoirs for microbial material. According to the review on microbes in house dust by Rintala et al. (2012), the studies using culturable methods have identified the fungal genera Penicillium, Aspergillus, Cladosporium and approximately 20 other genera as the most commonly isolated fungal genera in house dust. As expected, culture-independent studies have shown that both fungal and bacterial diversity is in fact far more extensive, with up to 500-1000 different species present in house dust (Rintala et al. 2004; Pitkäranta et al, 2008; Amend et al. 2010; Adams et al. 2013).

While indoor air concentrations of viable fungi usually remain inside the range $10^{1}-10^{3} \mathrm{CFU} / \mathrm{m}^{3}$, there are occupational environments where fungal exposures may exceed these with several orders of magnitude (Tsapko et al. 2011; Gora et al. 2009). Very large concentrations have been reported in agricultural environments, food industry, wood processing, waste sorting, and other occupations where organic material is being handled or processed. Examples of fungal concentrations in such environments are shown in Table 6-2.

These concentrations are also larger than those in normal outdoor air, and they are linked with many occupational diseases, such as allergic alveolitis.

\section{Bacteria-Introduction}

Bacteria are ubiquitous microorganisms present in soils, waters, plants, and other living organisms including humans (Starr et al. 1981) and they are also easily spread into the air (Després et al. 2012). Bacteria are prokaryotic organisms which replicate asexually by cell division. $\mathrm{S}$ to environmental stresses and environmental conditions. Bac survival (Colwell 2000). Bac gram negative and gram posit stain, and into rod-shaped bact Actinomycetes are separated ff a mycelium and sporulate sim:

Bacterial cells are typically may occur in air as single ce Bacterial spores are usually aro

Bacteria are found in the layers (Maki et al. 2013). The concentrations being lower in $v$ concentrations of bacteria may to $0.03 \%$ of the organic carbor concentrations over sea are mu methods, concentrations of airt bacteria types most often repori However, conclusions on the re are difficult due to high short- $t$ methods (Després et al. 2012).

Bacteria, similarly to fu: based methods, which allow tl characteristics of individual $c$ quantification and phenotypica a part of all bacteria can be culti 2003), and therefore cultural $\mathrm{m}$ of bacterial concentration in methods which may be based $\mathrm{c}$ biomass, or on immunological and thus give a more accurate :

\section{Bacteria in indoor envir}

For bacteria of indoor environ major sources of indoor bacteri. role of humans as sources of ir practically covered with benefic agents from outside. The outer $l_{i}$ every 4th day. As the skin scal environment carry bacterial colc levels of bacteria in any indoo: has been shown both using cult as chemical markers of bacteria indoor environment is dominat 
he germination and is that can produce rs or days (Pasanen reas in the building or another, e.g., by ure. Such moisture sld with naked eye. isociated with many ssired phenomenon ind toxic substances

;ource or as a sink of depends both on the 1. In an experimental 'es were aerosolized t no reaerosolization 1 higher loading was were noticed. Small ian larger Alternaria

a number of studies sulturable methods. lown that in indoor microbial material. 1. (2012), the studies icillium, Aspergillus, i commonly isolated Idies have shown that with up to 500-1000 tkäranta et al. 2008;

nain inside the range re fungal exposures al. 2011; Gora et al. Iltural environments, ations where organic sncentrations in such

outdoor air, and they veolitis.

ars, plants, and other are also easily spread aisms which replicate asexually by cell division. Some bacteria produce endospores that are resistant to environmental stresses and that may be activated for replication under suitable environmental conditions. Bacteria may also stay in a dormant state in order to ensure survival (Colwell 2000). Bacteria can be classified into different groups, such as gram negative and gram positive bacteria, depending on their ability to retain Gram stain, and into rod-shaped bacteria or spherical cocci based on morphological criteria. Actinomycetes are separated from other gram positive bacteria by their ability to form a mycelium and sporulate similarly to fungi.

Bacterial cells are typically of the size range from 1 to a few micrometers. Bacteria may occur in air as single cells and as aggregates or attached on other particles. Bacterial spores are usually around $1 \mu \mathrm{m}$ in their size, being smaller than those of fungi.

Bacteria are found in the atmospheric environment and also in the troposphere layers (Maki et al. 2013). Their concentrations have large temporal variability, the concentrations being lower in winter than in other seasons (Bertolini et al. 2013). Mean concentrations of bacteria may be more than $10^{4} \mathrm{~m}^{-3}$ over land areas, corresponding to $0.03 \%$ of the organic carbon content of the aerosol (Bauer et al. 2002), while the concentrations over sea are much lower (Prospero et al. 2005). Analyzed with cultural methods, concentrations of airborne bacteria may vary between $10^{2}-10^{5} \mathrm{CFU} \mathrm{m}{ }^{-3}$. The bacteria types most often reported are Firmicutes, Proteobacteria, and Actinobacteria. However, conclusions on the relative abundance of various bacteria in the atmosphere are difficult due to high short-term variability and biases from the different detection methods (Després et al. 2012).

Bacteria, similarly to fungi, can be analyzed and characterized by culture based methods, which allow the studying of various biochemical and physiological characteristics of individual organisms. Culture based methods are also used for quantification and phenotypical description of bacterial communities. However, only a part of all bacteria can be cultivated in laboratory conditions (Rappe and Giovannoni 2003 ), and therefore cultural methods may seriously underestimate the real magnitude of bacterial concentration in a given sample or environment. Non-culture-based methods which may be based on DNA analysis, use of chemical markers of bacterial biomass, or on immunological bioassays cover both viable and non-viable material and thus give a more accurate estimate of bacterial biomass or diversity.

\section{Bacteria in indoor environments}

For bacteria of indoor environments, outdoor air is an important source. However, major sources of indoor bacteria are humans and animals, such as pets. The important role of humans as sources of indoor bacteria is based on the fact that human skin is practically covered with beneficial, normal bacteria that protect the skin from harmful agents from outside. The outer layers of skin are continuously renewed, approximately every 4th day. As the skin scales that are then emitted into the individual's intimate environment carry bacterial colonies, the presence of humans is always seen as elevated levels of bacteria in any indoor environment. This human effect on indoor bacteria has been shown both using cultural methods, and by using non-cultural methods such as chemical markers of bacteria (Fox et al. 2005). The cultivable bacterial flora of the indoor environment is dominated by Gram-positive genera, such as Staphylococcus, 
Corynebacterium, and Lactococcus (Rintala et al. 2012), which are also common bacteria on human skin. Studies on indoor sources of bacteria have indeed shown that bed dust is typically dominated by species originating from the user of the mattress, whereas floor dust reflects more also outdoor sources (Täubel et al. 2009). Recent studies of indoor air using DNA based methods have come to similar conclusions as concerns the role of human occupants on indoor bacterial communities (Hospodsky et al. 2012; Meadow et al. 2013; Dunn et al. 2013).

High concentrations of bacteria are present in occupational environments where organic material is being handled, similarly to fungi and other biological particles (Gora et al. 2009). As fungi, bacteria, and other organisms occur together in various organic dusts, the exact role of each type of microorganisms in development of associated occupational diseases is not yet clear. Spore-forming actinomycetes, especially thermophilic species such as Thermoactinomyces vulgaris, are strongly associated with allergic alveolitis caused by moldy hay (doPico 1986).

\section{Bacterial endotoxins}

Bacterial endotoxin is a well-known component of the outer membrane of gram negative bacteria. It consists chemically of proteins, lipids, and lipopolysaccharide (LPS) but the term "endotoxin" is often used to emphasize its immunotoxic properties, which are also utilized in the quantification of endotoxin by the immunochemical Limulus assay (Heinrich et al. 2003). Water soluble LPS contains a hydrophobic lipid A and a long covalently linked hydrophilic heteropolysaccharide. Each genus, species, and strain of gram negative bacteria has a unique LPS with varying biological effects, although bacteria belonging to the same family typically have structurally similar LPS (Morrison and Ulevich 1978). Endotoxins are stable and heat-resistant molecules. As they are normal constituents of gram negative bacteria, which are present in practically all environments, also endotoxins are present everywhere. Endotoxins can occur in the air both as pure endotoxin, as parts of bacterial cells and carried by other particles. These compounds have significant inflammatory potential which may lead to various respiratory health effects among exposed individuals.

\section{Microbial toxins in indoor environments}

As presented above, bacterial endotoxins and glucans of fungi are normal constituents of bacterial and fungal cells and they have immunotoxic potential that is probably contributing to the health effects associated with exposures to biological particles and dusts. Another type of toxic compound linked with bacteria and fungi are microbial toxins that are produced as secondary metabolic products of these organisms. Toxins produced by fungi are called mycotoxins, but many species of both fungi and bacteria have the potential of producing highly bioactive and toxic secondary metabolites.

Mycotoxins are fungal secondary metabolites that pose a potential health risk to humans and/or animals due to the unusual toxicity of many such metabolites. The occurrence of toxigenic fungi in indoor environments is well documented as well as their ability to proliferate on various building materials, provided they are moist
(Nielsen 2003; Jarvis and Morey or dampness generally provide $\varepsilon$ seen as higher microbial levels it present also in 'normal' building: of mycotoxins is not only limitec associated toxigenic fungi are var: globosum, Wallemia sebi, Eur chartarum, to give a few examp of culturable Streptomyces spp. Many species of Streptomyces antimicrobial and immune-supp in the pharmaceutical industry.

Secondary metabolites of $m$ as amino acids, sugars, carbohy in the process of microbial grow is either in initiation of grow interactions between microorga the infectious fungus into the $\mathrm{pl}$ and different biological activiti such as sporogenic factors, pigm compounds are produced via org

To date, several hundreds characterized, the majority o agricultural settings; however, in the environment. Example are sterigmatocystin and aflat Mycotoxins are non-volatile, lo very stable and get airborne atte mycotoxin may be produced $b$ produce different mycotoxins. mycotoxins relates to ingestion suppressive, cytotoxic, and carc

There is an extensive lite bacterial toxin production unc document the occurrence of $t$ Nielsen et al. 1999; Gravesen 2011). The dispersal of mycot are released from the mycelius released in much higher numb Gorny et al. (2002). Thus, metl must apply relevant technique

Many studies from the lasi and bacterial toxins in indoor a to humans in these indoor envi Bloom et al. 2007, 2009; Täut Kirjavainen et al. 2015). 
are also common s indeed shown that ser of the mattress, :t al. 2009). Recent iilar conclusions as unities (Hospodsky

nvironments where biological particles together in various in development of ing actinomycetes, lgaris, are strongly 1986).

membrane of gram lipopolysaccharide unotoxic properties, e immunochemical a hydrophobic lipid Each genus, species, g biological effects, cturally similar LPS istant molecules. As resent in practically toxins can occur in dd by other particles. may lead to various

normal constituents tial that is probably logical particles and fungi are microbial e organisms. Toxins th fungi and bacteria idary metabolites. itential health risk to ch metabolites. The documented as well rided they are moist
(Nielsen 2003; Jarvis and Morey 2001). Indoor environments with moisture damage or dampness generally provide good growth conditions for microbes, which is also seen as higher microbial levels in such environments. However, toxigenic molds are present also in 'normal' buildings without moisture problems and thus the occurrence of mycotoxins is not only limited to damp indoor environments. Among the building associated toxigenic fungi are various Aspergillus and Penicillium species, Chaetomium globosum, Wallemia sebi, Eurotium spp., Trichoderma spp., and Stachybotrys chartarum, to give a few examples. As for bacteria, the detection of elevated levels of culturable Streptomyces spp. in buildings has been linked to moisture damage. Many species of Streptomyces are potent producers of bioactive metabolites with antimicrobial and immune-suppressing qualities and these bacteria are widely used in the pharmaceutical industry.

Secondary metabolites of microbes are different from primary metabolites-such as amino acids, sugars, carbohydrates - in that these compounds do not act directly in the process of microbial growth. The ecological function of secondary metabolites is either in initiation of growth and differentiation, or they act in competitive interactions between microorganisms to ensure survival, and facilitate the entry of the infectious fungus into the plant cell. There is a wide range of chemical structures and different biological activities within fungal and bacterial secondary metabolites, such as sporogenic factors, pigments, antibiotics, insecticides, or herbicides, and these compounds are produced via organized sets of genes following controlled mechanisms.

To date, several hundreds of different mycotoxins have been identified and characterized, the majority of which refers to food and feed contaminants in agricultural settings; however, up to 20,000 mycotoxins are estimated to be present in the environment. Examples of common and well characterized mycotoxins are sterigmatocystin and aflatoxin, ochratoxin, and macrocyclic trichothecenes. Mycotoxins are non-volatile, low molecular weight natural products that are typically very stable and get airborne attached to spores, fragments, and particulate matter. One mycotoxin may be produced by different fungal strains, and one fungal strain may produce different mycotoxins. Almost all of our knowledge on the modes of action of mycotoxins relates to ingestion exposure, where for example inflammatory, immunesuppressive, cytotoxic, and carcinogenic effects in various organs have been described.

There is an extensive literature documenting the potential of mycotoxin and bacterial toxin production under laboratory conditions but only few reports so far document the occurrence of toxins on naturally infested building materials (e.g., Nielsen et al. 1999; Gravesen et al. 1999; Bloom et al. 2007, 2009; Täubel et al. 2011). The dispersal of mycotoxins into indoor air may occur by intact spores that are released from the mycelium, or by fungal fragments (Brasel et al. 2005) that are released in much higher numbers than spores, as shown by Kildesø et al. (2003) and Gorny et al. (2002). Thus, methods to assess human exposure to airborne mycotoxins must apply relevant techniques to cover also the smallest particles.

Many studies from the last decade have indeed shown the presence of mycotoxins and bacterial toxins in indoor air and settled house dust, suggesting potential exposure to humans in these indoor environments (e.g., Engelhart et al. 2002; Brasel et al. 2005; Bloom et al. 2007, 2009; Täubel et al. 2011; Peitzsch et al. 2012; Polizzi et al. 2009; Kirjavainen et al. 2015). 


\section{Amoebae}

Amoebae are single-cell eukaryotic protozoans that constitute a diverse taxonomic group. The term "amoeba" is a practical term that refers to cells that are able to move and engulf food particles by producing projections of the cytoplasm. Amoebae are present in all aquatic environments all over the world (Rodriguez-Zaragoza 1994), whether natural or man-made. They are found, e.g., in drinking water, swimming pools, and eyewash stations from where amoebae can also be aerosolized and inhaled by humans.

Most amoebae are also able to exist in durable resting forms, cysts, in which the organism endures adverse conditions. Amoebae have a role in the ecosystem in the mineralizing of nitrogen, carbon, and phosphorus due to their importance as bacterial predators (Yli-Pirilä 2009). Not only do bacteria act as a source of nutrition for amoebae, but bacteria can also utilize amoebae as a vehicle for survival, replication, or as a means of transmission from one host to another. For example, legionellae are able to avoid digestion in the amoebae, but they can replicate inside amoebae until the amoebae burst (Newsome et al. 1998). This is one potential although indirect health effect of amoebae; they facilitate the spread of Legionella bacteria. Other possible health effects of amoebae include infections, e.g., in the eye.

Amoebae have been found in samples of mold growth associated with moisture damage of buildings (Yli-Pirilä 2009). This is an example of potential indoor exposure to amoebae. Experiments with associated bacteria and fungi showed that amoebae not only are members of the microbial network present in moisture-damaged, moldy building materials but they also have many interactions with other microbes present. Amoebae may increase the growth of other organisms, and render the microbes more cytotoxic, thus possibly modifying the health effect potential of microbes (Yli-Pirilä et al. 2006, 2007).

\section{Viruses}

Viruses are microorganisms that only can replicate within a host cell. Therefore, they cannot grow on nonliving substrates although they can survive and stay virulent on surfaces for days, in some cases even weeks (Casanova et al. 2010). Airborne survival time of viruses is much shorter (McDevitt et al. 2008). Viruses are usually specific to a certain species or group and they can infect bacteria, humans, animals, and plants. Viruses that replicate within bacterial cells are called bacteriophages.

Viruses are the smallest of microorganisms; their size range is $20-300 \mathrm{~nm}$ but they are often attached to other suspended particles (Yang and Marr 2011). The airborne behavior of viruses and the importance of their spread by the airborne route have not been well known until in recent years when molecular methods have been applied to the detection of airborne viruses. Viruses can be collected with bioaerosol collection devices and identified with molecular methods, but their airborne behavior has also been studied by modeling due to the technical difficulties of actual sampling and identification (Myatt et al. 2010).

\section{Pollen}

Pollen grains are part of the structure and transmitted long to other parts of the world. Tr of pollen grains end up on th. and other fragments of the $p$ range $30 \mathrm{~nm}-5 \mu \mathrm{m}$ (Miguel et are also distributed by insect plants being, e.g., many gras to the great influence of pol being monitored worldwide

\section{House dust mites}

House dust mites are small provided the $\mathrm{RH}$ of their mis scales and fungal spores anc produce allergenic proteins $i$ important causal agents of i1 are Dermatophagoides pter $\operatorname{Der} p$ I and $\operatorname{Der} f \mathrm{I}$, respecti are storage mites such as putrescentiae that may pro stores, and even homes. In and soft furniture, the mites often be storage mites (Cha

\section{Exposure, a prereq}

\section{Introduction}

Studying the health effects of exposure, which is definc agent in question. For docu relationship between the ag relationships is essential in to immunological and aller of biological exposures. Ir reaction which is strongly $b$ In any case, assessment of in the pursuit of understan

Exposure assessment and quantitative elements be used for collecting th analyzing the content. Der 


\section{Pollen}

iverse taxonomic ; are able to move sm. Amoebae are -Zaragoza 1994), water, swimming lized and inhaled

ysts, in which the ecosystem in the tance as bacterial : of nutrition for rival, replication, $e$, legionellae are amoebae until the sh indirect health ə. Other possible

ed with moisture 1 indoor exposure red that amoebae damaged, moldy nicrobes present. te microbes more srobes (Yli-Pirilä

1. Therefore, they I stay virulent on tirborne survival sually specific to mals, and plants. s.

$-300 \mathrm{~nm}$ but they 1). The airborne 1e route have not e been applied to erosol collection ehavior has also tal sampling and
Pollen grains are part of the reproduction system of plants that are stable in their structure and transmitted long distances as airborne; in optimal weather conditions even to other parts of the world. Their sizes vary between 10 and $100 \mu \mathrm{m}$ and therefore, a lot of pollen grains end up on the ground in nearby areas of the source. Pollen allergens and other fragments of the pollen grain may also occur in smaller particle sizes in the range $30 \mathrm{~nm}-5 \mu \mathrm{m}$ (Miguel et al. 2006; Matikainen and Rantio-Lehtimäki 1998). Pollen are also distributed by insects. Pollen may carry important allergens, major allergenic plants being, e.g., many grasses, ragweed, and trees such as birch and olive tree. Due to the great influence of pollen allergens on people's health, occurrence of pollen is being monitored worldwide through monitoring networks, programs, and databases.

\section{House dust mites}

House dust mites are small arachnids that occur in mattresses and other furniture, provided the $\mathrm{RH}$ of their microenvironment is $>55 \%$. They feed on, e.g., human skin scales and fungal spores and are typical contaminants of indoor environments. They produce allergenic proteins in their feces which can be aerosolized and are considered important causal agents of indoor environmental allergies. The most common species are Dermatophagoides pteronyssinus and $D$. farinae. Their major allergens are called $\operatorname{Der} p \mathrm{I}$ and $\operatorname{Der} f \mathrm{I}$, respectively (Chapman et al. 1987). Other allergenic mite species are storage mites such as Acarus siro, Glycyphagus domesticus, and Tyrophagus putrescentiae that may proliferate in food storage facilities in institutions, grocery stores, and even homes. In fact, while house dust mites are common in mattresses and soft furniture, the mites that are found within a mold growth on a wall, may more often be storage mites (Charpin et al. 2010).

\section{Exposure, a prerequisite to health effects}

\section{Introduction}

Studying the health effects of environmental agents is always bound to the assessment of exposure, which is defined as the contact between the human and the environmental agent in question. For documentation of a causal connection, usually a dose-response relationship between the agent and the effect is needed. The concept of dose-response relationships is essential in the toxicological paradigm but cannot be applied as such to immunological and allergic reactions that are common in relation to health effects of biological exposures. In allergic conditions, the dose is often not critical for the reaction which is strongly bound to the individual characteristics of the exposed person. In any case, assessment of exposure and the studies on its determinants are essential in the pursuit of understanding the health effect of environmental agents.

Exposure assessment of environmental biological agents includes both qualitative and quantitative elements. There is a wide selection of methods available that can be used for collecting the samples from the environment and for detecting and analyzing the content. Depending on the aims of the investigation, the focus may be 
on characterization of the microbial communities present in the sample, on quantitation of fungal or bacterial biomass, on specific quantitation of a species, or a group of microbes or some other approach.

Sampling and characterization of the microbial community with culturing methods covers both qualitative and quantitative aspects but the method is selective, favoring those species for which the sampling technique and culture medium used are optimal. Culturing methods do not detect non-viable microbial material. Sequencing methods give an overall picture of the microbial DNA present, but for more precise quantification of a species or genus, additional analysis with qPCR is needed. In cases where quantification of microbial biomass is of interest, analyses of chemical markers such as ergosterol for assessment of fungal biomass is a good choice.

Most biological particles, fungi, bacteria, and other such material are present everywhere, in soil, water, air, and in built environments. They are part of the natural background of atmospheric particles and they are generally transported long distances around the world. Their occurrence in the atmosphere is regulated by geographical and climatic conditions as well as local events and circumstances. Humans get exposed to these particles both via outdoor air and via indoor air. People spend most of their time indoors, therefore, it is evident that the exposures that take place indoors make the major contribution of total exposures to biological particles, given that indoor concentrations are not considerably lower than outdoors. Whether the importance of indoor exposures for health is greater than the exposures outdoors is not quite clear. For example, pollen are important allergens and exposure to them takes place mainly outdoors, while the health effects of bio-particles that are linked with moisture and mold damage of buildings have their origin in the indoor environments.

Evaluation of the health effects of environmental stressors comprises of assessment of exposure and of evaluation of the health effects of the measured concentrations. Exposure assessment is based on specific sampling techniques and procedures optimized for each agent and on subsequent analysis that allows quantification of the measured agent. Sampling and analysis techniques of biological particles have been specifically developed for various biological particles. It should be emphasized that no single methodology allows the quantitative and qualitative determination of all biological particles in parallel, but each method is selective and focuses on certain characteristics of the measured material, be it enumeration of a group of microbes, or quantification of material with certain immunological activity, for example, endotoxin.

\section{Sampling of biological particles}

Sampling of biological particles from air is based on similar principles as any aerosol sampling. Air samplers can be designed for the detection of culturable or non-culturable material. Sampling devices may be passive samplers using natural aerosol convection, diffusion or gravity, or active samplers using stationary or personal pumps (Nevalainen et al. 1992; An et al. 2004). Various impactors, impingers, centrifugal samplers, and filters are in common use. Biological particles can be collected on culture medium, i.e., agar plates in impactors, or into a liquid medium in an impinger. These collection methods are followed by cultu that can be counted and identi developed to avoid bouncin: in impactors (Lin et al. 1999 where the collected material chemical, immunochemical, been developed (e.g., Yao ar presented and evaluated in, $\epsilon$

Active sampling of bio concentrations. Especially w labor-intensive approach as $\epsilon$ In population-scale studies, $t$ Recent progress in epidemi environmental exposures in cost sampling methods that : in the same study. For such : been developed, as house $c$ material of the indoor envi exposure assessment of indc samples can be done, e.g., b surfaces, or by passive coller the passive collection metho representative in the sense 6 shown useful and as having studies. A major part of the is linked with house dust : Ege et al. 2011).

\section{Analysis of biological}

The analysis of a collected bacteria, or on non-cultivati

Fungi and bacteria are $\mathrm{c}$ properties for their content $c$ the composition of the cultur light, time, and availability ' certain groups or types of 1 approach is typically used $r$ in environmental sampling sample is usually of intere: are used, such as malt extr microbes are usually low $\mathrm{i}$ : nutritional conditions of the

Even with the non-sele be grown into visible color 
2 , on quantitation $s$, or a group of with culturing hod is selective, nedium used are rial. Sequencing for more precise needed. In cases hemical markers e.

erial are present art of the natural zd long distances zeographical and lans get exposed ind most of their ce indoors make iven that indoor re importance of $s$ not quite clear. kes place mainly ith moisture and ints.

ses of assessment I concentrations. and procedures ntification of the ticles have been emphasized that rmination of all cuses on certain $\mathrm{p}$ of microbes, or mple, endotoxin.

es as any aerosol or non-culturable :osol convection, mps (Nevalainen ;al samplers, and culture medium, These collection methods are followed by culturing of the collected microorganisms into visible colonies that can be counted and identified. Centrifugal sampling into a viscous liquid has been developed to avoid bouncing and stress to the collected cells, typical phenomena in impactors (Lin et al. 1999). Sampling on filters is a natural choice in those cases where the collected material is not cultured but suspended for further analysis with chemical, immunochemical, or DNA based methods. Also, electrostatic sampling has been developed (e.g., Yao and Mainelis 2006). Bioaerosol samplers are extensively presented and evaluated in, e.g., Reponen et al. (2011).

Active sampling of biological particles aims at an accurate assessment of air concentrations. Especially with indoor environmental sampling, this usually means a labor-intensive approach as each sampling site must be visited by the sampling staff. In population-scale studies, this is often beyond the economic resources of the study. Recent progress in epidemiological research that aims to link health effects with environmental exposures in home environments has led to the development of low cost sampling methods that allow studying of, e.g., hundreds or thousands of homes in the same study. For such studies, standardized methods to collect house dust have been developed, as house dust is considered an important reservoir of microbial material of the indoor environment. House dust sampling has also been used for exposure assessment of indoor toxicants (Lioy et al. 2002). Collection of house dust samples can be done, e.g., by vacuuming house dust from floors, mattresses or other surfaces, or by passive collection of settling dust (Kaarakainen et al. 2009). Although the passive collection methods or different ways of sampling house dust are not quite representative in the sense of aerosol sampling, these sampling methods have been shown useful and as having cost-benefit advantages especially in large population studies. A major part of the health data that is related to indoor microbial exposures, is linked with house dust sampling as the method of exposure assessment (e.g., Ege et al. 2011).

\section{Analysis of biological particles}

The analysis of a collected sample may be based on cultivation of viable fungi or bacteria, or on non-cultivation methods.

Fungi and bacteria are cultivated using different culture media. They have different properties for their content of nutrients, water activity, and growth suppressants. With the composition of the culture medium and by regulating growth temperature, humidity, light, time, and availability of oxygen, the conditions can be set to an optimal state for certain groups or types of microorganisms which facilitates their observation. This approach is typically used when certain pathogenic species are looked for. However, in environmental sampling, the whole range of the microorganisms present in the sample is usually of interest. Therefore, non-selective media for fungi and bacteria are used, such as malt extract agar. Non-selective growth media for environmental microbes are usually low in their nutrient content which imitates the typically poor nutritional conditions of their natural environment.

Even with the non-selective growth media, only a part of the species present can be grown into visible colonies. Those cells that are somehow damaged or for which 
the given medium and growth conditions are not optimal will probably not grow, and those with too long germination or division time are not seen as the space on the growth medium is usually limited and occupied fast by the most easily growing species. Furthermore, there are plenty of microbes that cannot be cultured in laboratory conditions. In fact, it has been assessed that only $1-10 \%$ of all the microbial cells present in environmental samples can be quantified and identified with cultural methods.

While cultivation based methods have historically been widely used in indoor microbial assessments and reference data are extensive, these approaches suffer from well-known limitations, which has triggered the rise of alternative, molecular methods. These are DNA based methods, analyses of chemical markers of microbial biomass, and immunochemical methods. Some agents can also be directly counted from a sample with a microscope, for example, pollen or certain types of fungal spores. A main factor driving this development is that a vast majority of microbial mass around us is not cultivable and/or not viable. From a health perspective-with the health of people being the main reason for why we aim to assess exposure- both not cultivable and dead microbes and their constituents are relevant in addition to the viable portion of the exposure. Cultivation based approaches in indoor assessments have typically been applied in combination with impaction-based, active air sampling, with short-term air sampling as such being problematic already. Active air sampling in the field and the need for cultivation/identification of microbes is an equipment intensive, laborious process (during sample collection) that requires time and expertise (in the laboratory analyses) and thus is only poorly applicable to larger-scale epidemiological studies. In the following, we provide a short overview of some of the methods that are applied in epidemiological study settings that aim to clarify the impacts of indoor microbial exposures on human health.

\section{DNA-based methods}

It is long known that the majority of micro-organisms is uncultivable under laboratory conditions, with estimates of $10 \%$ to less than $0.01 \%$ of the microbiome being captured with cultivation, depending on the habitat. For samples from indoor air, the ratio of total fungi and bacteria-assessed via microscopic counting-to viable fungi and bacteria, was estimated with 100:1 (Toivola et al. 2002). A way out of this dilemma of the 'uncultivable majority' (Pitkäranta 2012) was offered with the rise of polymerase chain reaction and other DNA based technologies that would allow to circumvent the need of cultivation prior to quantification and identification of microbes. Today, cultivation-independent methods, that is DNA targeting methods as well as immuno-/ bioassays and chemical analytical approaches for quantifying microbial cell wall components, are routinely used in the characterization and monitoring of indoor microbial exposures.

The initial step in all DNA-based methods is the extraction of DNA directly from a given environmental sample. There is a multitude of different extraction methods, but typically microbial cells first get suspended from the sample matrix (in indoor 
obably not grow, 1 as the space on st easily growing ured in laboratory e microbial cells ted with cultural

ly used in indoor aches suffer from olecular methods. icrobial biomass, ted from a sample res. A main factor around us is not health of people ot cultivable and viable portion of ve typically been ith short-term air the field and the ensive, laborious in the laboratory iological studies. $s$ that are applied indoor microbial

under laboratory 1e being captured ir air, the ratio of viable fungi and $\mathrm{f}$ this dilemma of se of polymerase $\mathrm{w}$ to circumvent nicrobes. Today, vell as immuno-/ crobial cell wall toring of indoor

NA directly from raction methods, aatrix (in indoor studies, e.g., an air filter, indoor dust, or a building material); the cell envelopes are then mechanically or/and enzymatically disrupted to free the intracellular DNA, which then is further purified for subsequent analyses steps.

Common to most of the currently used approaches that aim at characterizing microbial communities or at quantifying microbial exposure is the amplification of a target gene fragment, that occurs ubiquitously in all microbes of interest, e.g., all bacteria or all fungi and contains phylogentically informative regions that allows differentiation of microbes on different taxonomic levels. These target sequences are usually amplified using a polymerase chain reaction and are then utilized in different DNA based methods, including quantitative PCR, fingerprinting, and sequencing approaches. Most commonly used for this purpose are the 16S ribosomal RNA gene in bacteria (16S rDNA) and the nuclear internal transcribed spacer region (ITS or nucITS) located between $18 \mathrm{~S}, 5.8 \mathrm{~S}$, and $28 \mathrm{~S}$ rRNA genes in fungi. Highly conserved regions within these $16 \mathrm{~S}$ rDNA or ITS sequences allow the designing of oligonucleotide primers and probes that will target bacteria and fungi on a higher taxonomic level, for example, using 'universal' primers that will allow detection of the majority of organisms within the respective kingdom, or group specific primers. More specific stretches within the 16S rDNA and ITS regions-specific for a given group of closely related microbes - can be used to target a certain bacterial or fungal genus or species of interest. In essence, the differences in variability/conservation within these 'barcode' gene sequences, as they are often referred to, allow targeting of microbial groups at various taxonomic levels.

\section{QPCR methods}

The characteristic of the barcode gene sequences, i.e., targeting of microbial groups at different levels of resolution, is widely exploited in quantitative PCR (qPCR) methods that have been recently applied for the assessment of indoor exposure to microbes. Displaying the accumulation of a fluorescently labeled product during PCR amplification in 'real time' and comparing it to a standard curve based on amplifications of known concentrations of the target gene sequence allows the quantification of the original amount of the target gene or target organism (number of spores) in an environmental sample.

QPCR method is sensitive and fast; DNA extraction and qPCR analyses of an environmental sample can be performed within hours, where cultivation based methods required days to weeks. The specificity of the qPCR depends on the qPCR primers and probes that are applied. Since the initial applications of qPCR as a tool to assess exposure to the toxigenic fungus Stachybotrys chartarum in indoor environments more than a decade ago (Haugland et al. 1999), a large number of qPCR assays has been designed for various indoor fungal species, genera, or groups, and a number of bacterial genera and species thought to be relevant in indoor environments. A good part of these efforts on qPCR assay development (Haugland and Vesper 2002) has been facilitated by the US Environmental Protection Agency (US EPA) and has been 
complemented by individual research groups (e.g., Rintala and Nevalainen 2006; Torvinen et al. 2010; Kärkkäinen et al. 2010; Yamamoto et al. 2010).

QPCR analysis in the context of indoor environmental research and monitoring has been applied on building material samples, house dust, and indoor air collected via filtration of air. Generally, higher prevalence is observed for individual microbial species and overall microbial levels measured with qPCR are usually orders of magnitude higher than those found with cultivation based approaches. This confirms what has already been known, i.e., that cultivation-based approaches clearly underestimate both diversity and quantities of microbial exposures indoors. QPCR has been shown to be a useful tool in research investigating the effects of indoor microbial exposures on human health. This method is also used in practical situations in order to identify abnormal microbial conditions in buildings, usually in the context of moisture damage and indoor dampness. However, especially in order to be a useful diagnostic tool for building practitioners, profound knowledge is needed on what is a normal situation in a given country/climatic region. Unlike for cultivation-based approaches, extensive reference datasets thus far do not exist. Another technical limitation is that targeting, for example, a specific fungal species in a sample will provide quantitative information for only this one targeted species, but one stays blind for any other fungal taxa in a sample. This is different from cultivation based approaches, where with one cultivation a multitude of different fungal taxa can be quantified.

\section{DNA fingerprinting methods}

Different DNA fingerprinting methods have been applied on some occasions in indoor environmental studies, typically with the aim to follow changes or identify differences in bacterial or fungal communities, or to use the DNA fingerprints as a proxy for microbial diversity in a sample (Ege et al. 2011). Examples for these methods are terminal fragment length polymorphism (tRFLP), single-strand conformational polymorphism (SSCP), temperature- and denaturing gradient gel electrophoresis (TGGE and DGGE, respectively). What all these methods have in common is that they start from a pool of rather general PCR amplicons (e.g., universal bacterial or universal fungal amplicons) obtained from an environmental sample, with single amplicons then being separated based on differences in DNA sequences, producing a fingerprint of different bacterial or fungal species in a given sample. This method is useful in comparing microbial communities in tens or even hundreds of different samples; however, due to limitations in sensitivity and resolution of these methods, only major changes in the more abundant microbial groups can be reliably observed. Working with DNA fingerprinting methods is rather laborious, especially when one attempts to identify a specific microbial group that is associated with a change in the microbial community. This may be the reason why this method has not been widely applied in indoor exposure studies.

\section{Sequencing methods}

Similar to DNA fingerprinting, most sequencing methods currently applied utilize a pool of typically 'universal' bacterial or fungal PCR amplicons from an environmental sample. However, rather tha approaches attempt obtainis given sample. Traditional se costly and time-consuming. including different methoc platforms, have improved : of hundreds of samples an sample can be convenientl of information that is prodi pressure on the developme mass of information in a ( been made in this field it st: sequencing data lag behind extensive and detailed data

DNA-targeting approar our view on microbes and th and their role in human $h_{1}$ overcome limitations of $\mathrm{c}$ by allowing processing of However, DNA-approachs new type of uncertainties $t$

\section{Chemical markers}

Composition of the microb of chemical markers that $p$ example, ergosterol is ste1 by determining the ergoste (Saraf et al. 1997). Simile Gram positive bacteria, an (Sebastian and Larsson 21 lipid A component of lipop used as a marker of Gram

These compounds are and therefore, prior to at purified by extractions, $d \epsilon$ tandem mass spectrometr

\section{Bioassays}

Bioassays can be used fo specific biological activity assay for endotoxin, whi bacterial LPS. The assay c The assay is based on $\mathrm{e}$ 
Jevalainen 2006; )).

$\mathrm{h}$ and monitoring loor air collected ividual microbial isually orders of es. This confirms Jroaches clearly idoors. QPCR has indoor microbial lations in order to intext of moisture useful diagnostic what is a normal ased approaches, limitation is that vide quantitative - any other fungal $i$, where with one

me occasions in unges or identify fingerprints as a or these methods I conformational electrophoresis common is that irsal bacterial or ple, with single nces, producing jle. This method reds of different $f$ these methods, :liably observed. cially when one 1 a change in the not been widely

applied utilize a n environmental sample. However, rather than profiling these amplicons into a fingerprint, sequencing approaches attempt obtaining the DNA sequences of each single PCR fragment in a given sample. Traditional sequencing methods using Sanger chemistry still were both costly and time-consuming. The so-called "next-generation" sequencing approaches, including different methods such as 454 pyrosequencing or Illumina sequencing platforms, have improved sample throughput and greatly reduced costs. Processing of hundreds of samples and obtaining thousands to millions of sequence reads per sample can be conveniently done within a matter of hours. The enormous amount of information that is produced with these novel sequencing techniques has created pressure on the development of bioinformatics tools that would be able to process mass of information in a (biologically) meaningful way. While great progress has been made in this field it still feels that ways to analyze and interpret next generation sequencing data lag behind the technological possibilities to produce more and more extensive and detailed datasets.

DNA-targeting approaches and especially sequencing methods have revolutionized our view on microbes and their role in environmental and human microbial ecosystems and their role in human health and disease. These methods have indeed proven to overcome limitations of cultivation-based approaches by being less selective and by allowing processing of large sample quantities in highly automated processes. However, DNA-approaches also have technical limitations and have introduced a new type of uncertainties that need to be considered in applications of such methods.

\section{Chemical markers}

Composition of the microbial communities can be studied by determining the amounts of chemical markers that present overall proportions of different microbial groups. For example, ergosterol is sterol specific and universally present in all fungal cells, and by determining the ergosterol content of the sample, fungal biomass can be quantified (Saraf et al. 1997). Similarly, muramic acid is present in bacterial cells, more so in Gram positive bacteria, and it is used as a marker of (Gram positive) bacterial biomass (Sebastian and Larsson 2003). Furthermore, 3-hydroxy-fatty acids that are found in lipid A component of lipopolysaccharide of Gram negative bacteria, can be specifically used as a marker of Gram negative bacteria (Saraf et al. 1997).

These compounds are covalently linked to various structures in the cell membranes, and therefore, prior to analysis, samples are hydrolyzed to cleave these linkages, purified by extractions, derivatised and finally analyzed, using gas chromatographytandem mass spectrometry (GC-MS/MS).

\section{Bioassays}

Bioassays can be used for quantification of microbial biomass by determining their specific biological activity. A commonly used bioassay is the Limulus amebocyte lysate assay for endotoxin, which is the method used to describe the biological activity of bacterial LPS. The assay can also be used to determine the fungal beta (1->3)-D-glucan. The assay is based on enzymatic cascade of amebocytes isolated from horseshoe 
crab Limulus which has the specific capacity to react with bacterial LPS or fungal $\beta-(1->3)$-D-glucan in a dose-response pattern.

Endotoxin concentrations are expressed as either endotoxin units, based on the immunological activity in the Limulus assay, or as SI units ng $\mathrm{m}^{-3}$, where the amount of LPS has been calculated either from the bioassay or from gas chromatography-mass spectrometry analysis of the bacterial cell fragments that are proportional to amounts of the corresponding macromolecular structures (Larsson 1994).

Allergens, fungal glucans and extracellular polysaccharides are detected with specific immunochemical methods where a known antibody is bound with the antigen that is being analyzed. Biological particles are often analyzed with enzyme-linked bioassay (ELISA).

\section{Metrics and units to describe the quantity of microbial material in a sample}

As there are many different ways to analyze the biological content of an environmental sample, there also are a number of different ways of expressing the concentrations of biological particles or biological material in a sample. Only a few of such units belong to the metric system. Therefore, comparison of concentrations or exposure levels and summarizing the results from different studies may be difficult due to lack of common metrics of the determinations.

When culturable methods are used to quantify fungi or bacteria, the unit is usually $\mathrm{CFU} \mathrm{m}{ }^{-3}$, 'colony forming units per cubic meter of air' or CFU g ${ }^{-1}$ of dust or building material. The term 'colony forming unit' is based on the fact that the microbial colonies that are counted from the cultivation media surface may originally have been either single cells or aggregates of several cells. In some direct-calculation methods where bioparticles can be counted directly from the collection surface using a microscope, the used unit may be simply $\# \mathrm{~m}^{-3}$.

In DNA based sequencing techniques, the number of taxonomic units that have been identified in a given sample, are many times expressed as 'OTU's', or operational taxonomic units per sample. Such a operational taxonomic unit is defined based on sequence similarity; a similarity of $97 \%$ in the DNA sequence of the bacterial $16 \mathrm{~S} \mathrm{rRNA}$ gene, for example, is commonly used to group sequences into OTUs. Such a level of sequence similarity is believed to compare close to the common species concept that is however also based on morphology, physiology, and other characteristics of organisms, and therefore, 'species' and 'OTUs' are not fully comparable. QPCR results can be calculated to give the amount of the target organism as specific DNA amount or cell equivalents per sample mass.

When chemical methods are used to assess the microbial biomass, the concentration of the marker is usually expressed as mass units per sampled volume of air or per sample mass, for example, for ergosterol in house dust, $\mathrm{x} \mathrm{ng} \mathrm{g}^{-1}$. An expression of $\mathrm{x}$ mmol g${ }^{-1}$ may also be used. In case of samples that have been vacuumed from a surface, the concentration may be expressed as surface loading per sampled area. When immunological assays such as Limulus assay for endotoxin are used, typically the unit is 'international endotoxin units'. 
srial LPS or fungal

units, based on the , where the amount :omatography-mass ortional to amounts

$s$ are detected with ind with the antigen vith enzyme-linked

\section{bial material}

of an environmental 1e concentrations of of such units belong exposure levels and it to lack of common $a$, the unit is usually ${ }^{1}$ of dust or building e microbial colonies ly have been either tion methods where using a microscope,

mic units that have 'U's', or operational tit is defined based nce of the bacterial :es into OTUs. Such he common species other characteristics comparable. QPCR $\mathrm{sm}$ as specific DNA

ss, the concentration olume of air or per ${ }^{1}$. An expression of $n$ vacuumed from a s per sampled area. 1 are used, typically

\section{References}

Adams, R.I., M. Miletto, J.W. Taylor and T.D. Bruns. 2013. Dispersal of microbes: Fungi in indoor air are dominated by outdoor air and show dispersal limitation short distances. ISME J. 7: 1262-1273.

Adan, O.C.G. and R.A. Samson. 2011. Introduction. pp. 15-38. In: O.C.G. Adan and R.A. Samson [eds.]. Fundamentals of Mold Growth in Indoor Environments and Strategies for Healthy Living. Wageningen Academic Publishers, Wageningen, The Netherlands.

Alwis, K.U., J. Mandryk and A.D. Hocking. 1999. Exposure to biohazards in wood dust: bacteria, fungi, endotoxins, and beta(1->3)-D-glucans. Appl. Occup. Environ. Hyg. 14: 598-608.

Amend, A.S., K.A. Seifert, R. Samson and T.D. Bruns. 2010. Indoor fungal composition is geographically patterned and more diverse in temperate zones than in the tropics. Proc. Natl. Acad. Sci. 12107: $13748-13753$.

An, H.R., G. Mainelis and M. Yao. 2004. Evaluation of a high-volume portable bioaerosol sampler in laboratory and field environments. Indoor Air 14: 385-393.

Andreae, M.O. and D. Rosenfeld. 2008. Aerosol-cloud-precipitation interactions. Part 1. The nature and sources of cloud-active acrosols. Earth Sci. Rev. 89: 13-41.

Bauer, H., A. Kasper-Giebl, M. Löflund, H. Giebl, R. Hitzenberger, F. Zibuschka and H. Puxbaum. 2002. The contribution of bacteria and fungal spores to the organic carbon content of cloud water, precipitation and aerosols. Atmos. Res. 64: 109-119.

Bertolini, V., I. Gandolfi and R. Ambrosini. 2013. Temporal variability and effect of environmental variables on airborne bacterial communities in an urban area of Northern Italy. Appl. Microbiol. Biotechnol. 97: $6561-6570$.

Bloom, E., K. Bal, E. Nyman, A. Must and L. Larsson. 2007. Mass-spectrometry-based strategy for direct detection and quantification of some mycotoxins produced by Stachybotrys and Aspergillus spp. in indoor environments. Appl. Environ. Microbiol. 73: 4211-4217.

Bloom, E., E. Nyman and A. Must. 2009. Molds and mycotoxins in indoor environments-a survey in water-damaged buildings. J. Occup. Environ. Hyg. 6: 671-678.

Bowers, R.M., N. Clements and J.B. Emerson. 2013. Seasonal variability in bacterial and fungal diversity of the near-surface atmosphere. Environ. Sci. Technol. 47: 12097-12106.

Brasel, T.L., J.M. Martin, C.G. Carriker, S.C. Wilson and D.C. Straus. 2005. Detection of airborne Stachybotrys chartarum macrocyclic trichotecenes in the indoor environment. Appl. Environ. Microbiol. 72: 7376-7388.

Burge, H. 1990. Bioaerosols: Prevalence and health effects in the indoor environment. J. Allergy Clin. Immunol. 86: 687-701.

Casanova, L.M., S. Jeon, W.A. Rutala, D.J. Weber and M.D. Sobsey. 2010. Effects of air temperature and relative humidity on coronavirus survival on surfaces. Appl. Environ. Microbiol. 76: 2712-2717.

Chapman, M.D., P.W. Heymann, S.R. Wilkins, M.J. Braun and T.A.E. Platts-Mills. 1987. Moniclonal immunoassays for major dust mite (Dermatophagoides) allergens, $\operatorname{Der} p \mathrm{I}$ and $\operatorname{Der} f \mathrm{I}$, and quantitative analysis of the allergen content of mite and house dust extracts. J. Allergy Clin. Immunol. 80: 184-194.

Charpin, D., P. Parola, I. Arezki, C. Charpin-Kadouch, A. Palot and H. Dumon. 2010. House-dust mites on wall surfaces of damp dwellings belong to storage mite genus. Allergy 65: 274-275.

Colwell, R. 2000. Viable but nonculturable bacteria: a survival strategy. J. Infect. Chemother. 6: 121-125.

Després, V.R., J.A. Huffman, S.M. Burrows, C. Hoose, A.S. Safatov, G. Buryak, J. Fröhlich-Nowoisky, W. Elbert, M.O. Andreae, U. Pöschl and R. Jaenicke. 2012. Primary biological aerosol particles in the atmosphere: a review. Tellus B 64: 15598 .

doPico, G.A. 1986. Health effects of organic dusts in the farming environment. Report of diseases. Am. J. Ind. Med. 10: 261-265.

Douwes, J. 2005. (1->3)-beta-D-glucans and respiratory health: a review of scientific evidence. Indoor Air 15: 160-169.

Dunn, R.R., N. Fierer, J.B. Henley, J.W. Leff and H.L. Menninger. 2013. Home life: factors structuring the bacterial diversity found within and between homes. PLOS ONE 8:3 e64133.

Durand, K.T.H., M.L. Muilenberg, H.A. Burgeand and N.S. Seixas. 2002. Effect of sampling time on the culturability of airborne fungi and bacteria sampled by filtration. Ann. Occup. Hyg. 46: 113-118.

Ege, M., M. Mayer, A.-C. Normand, J. Genuneit, W.O. Cookson, C. Braun-Fahrländer, D. Heederik, R. Piarroux, E. von Mutius and the GABRIELA/TR22 study group. 2011. Exposure to environmental microorganisms and childhood asthma. N. Engl. J. Med. 364: 701-709. 
Engelhart, S., A. Loock, D. Skutlarek, H. Sagunski, A. Lommel, H. Färber and M. Exner. 2002. Occurrence of toxigenic Aspergillus versicolor isolates and sterigmatocystin in carpet dust from damp indoor environments. Appl. Environ. Microbiol. 68: 3886-3890.

Fox, A., W. Harley, C. Feigley, D. Salzberg, C. Toole, A. Sebastian and L. Larsson. 2005. Large particles are responsible for elevated bacterial marker levels in school air upon occupation. J. Environ. Monit. 7: $450-456$

Frankel, M., G. Beko, M. Timm, S. Gustavsen, E.W. Hansen and A.M. Madsen. 2012. Seasonal variations in indoor microbial exposures and their relation to temperature, relative humidity, and air exchange rate. Appl. Environ. Microbiol. 78: 8289-8297.

Gehring, U., J. Heinrich, G. Hoek, M. Giovanangelo, E. Nordling, T. Bellander, J. Gerritsen, J.C. de Jongste, H.A. Smit, H.E. Wichmann, M. Wickman and B. Brunekreef, 2007. Bacteria and mould components in house dust and children's allergic sensation. Eur. Respir. J. 29: 1144-1153.

Gora, A., B. Mackiewicz, P. Krawczyk, M. Golec, S. Skórska, G. Cholewa, L. Larsson, M. Jarosz, A. Wójcik-Fatla and J. Dutkiewicz. 2009. Occupational exposure to organic dust, microorganisms, endotoxin and peptidoglycan among plant processing workers. Ann. Agric. Environ. Med. 16: 143-150.

Góny, R.L., T. Reponen, K. Willeke, D. Schmechel, E. Robine, M. Boissier and S.A. Grinshpun. 2002. Fungal fragments as indoor air biocontaminants. Appl. Environ. Microbiol. 68: 3522-3531.

Gravesen, S. 1979. Fungi as a cause of allergic disease. Allergy 34: 135-154.

Gravesen, S., L. Larsen and P. Skov. 1983. Aerobiology of schools and public institutions-part of a study. Ecol. Dis. 2: 411-413.

Gravesen, S., P.A. Nielsen, R. Iversen and K.F. Nielsen. 1999. Microfungal contamination of damp buildings-examples of risk constructions and risk materials. Environ. Health Perspect. 107 Suppl. 3: $505-508$

Green, B.J., E.R. Tovey, J.K. Sercombe, F.M. Blachere, D.H. Beezhold and D. Schmechel. 2006. Airborne fungal fragments and allergenicity. Med. Mycol. 44: S245-S255.

Haas, D., J. Habib, H. Galler, W. Buzina, R. Schlacher, E. Marth and F.F. Reinthaler. 2007. Assessment of indoor air in Austrian apartments with and without visible mold growth. Atmos. Environ. 41 $5192-5201$

Haugland, R. and S. Vesper. 2002. Method of identifying and quantifying specific fungi and bacteria. US Patent 6387652.

Haugland; R.A., S.J. Vesper and L.J. Wymer. 1999. Quantitative measurement of Stachybotrys chartarum conidia using real tim e detection of PCR products with the TaqMan ${ }^{\mathrm{TM}}$ fluorogenic probe system. Mol. Cell. Probes. 13: 329-340.

Heinrich, J., B. Hölscher, J. Douwes, K. Richter, A. Koch, W. Bischof, B. Fahlbusch, R.W. Kinne, H.E. Wichmann and INGA Study Group. 2003. Reproducibility of allergen, endotoxin and fungi measurements in the indoor environment. J. Expo. Anal. Environ. Epidemiol. 13: 152-160.

Hospodsky, D., J. Qian, W.W. Nazaroff, N. Yamamoto, K. Bibby, H. Rismani-Yazdi and J. Peccia. 2012 Human occupancy as a source of indoor air bacteria. PLoS ONE 7: e34867.

Jaenicke, R. 2005. Abundance of cellular material and proteins in the atmosphere. Science 308: 73 .

Jarvis, J.Q. and P.R. Morey. 2001. Allergic respiratory disease and fungal remediation in a building in a subtropical climate. Appl. Occup, Environ. Hyg. 16: 380-388.

Kaarakainen, P., H. Rintala, A. Vepsäläinen, A. Hyvärinen, A. Nevalainen and T. Meklin. 2009. Microbial content of house dust samples determined with qPCR. Sci. Total Environ. 407: 4673-4680.

Kärkkänen, P., M. Valkonen, A. Hyvärinen, A. Nevalainen and H. Rintala. 2010. Determination of bacterial load in house dust using qPCR methods, chemical markers and culture. J. Environ. Monit. 12: 759-768.

Kildesø, J., H. Würtz, K.F. Nielsen, P. Kruse, K. Wilkins, U. Thrane, S. Gravesen, P.A. Nielsen and T. Schneider. 2003. Determination of fungal spore release from wet building materials. Indoor Air 13: $148-155$.

Kirjavainen, P.V., M. Täubel, A.M. Karvonen, M. Sulyok, P. Tiittanen, R. Krska, A. Hyvärinen and J. Pekkanen. 2015. Microbial secondary metabolites in homes in association with moisture damage and asthma. Indoor Air doi: 10.1111/ina.12213.

Korpi, A., J. Jamberg and A.-L. Pasanen. 2009. Microbial volatile organic compounds. Crit. Rev. Toxicol. 39: 139-193.

Kuo, Y.M. and C.S. Li. 1994. Seasonal fungus prevalence inside and outside of domestic environments in the subtropical climate. Atmos. Environ. 28: 3125-3130.
Larsson, L. 1994. Determ spectrometry-potenti; Immunol. Scand. 102:

Lehtonen, M., T. Reponen $\varepsilon$ concentration in indoos

Levetin, E., R. Shaughnessy, schools: exposure to fu

Lin, X.J., T.A. Reponen, K. sampling of airborne ba

Lioy, P.J., N.C.G. Freeman an assessment and source

Macher, J.M., F.Y. Huang an a new apartment. Arch

Maki, T., M. Kakikawa, F. Assessment of compos Environ. 74: 73-82.

Matikainen, E. and A. Rantis airborne birch pollen reports. Grana 37: 293

McDevitt, J.J., D.K. Milton, UVC light in a simulat

Meadow, J.F., A.E. Altrichte communities are influ 10.1111/ina. 12047

Meklin, T., T. Husman, A. Moschandreas and A. I in moisture damaged a

Miguel, A.G., P.E. Taylor, J. respirable fragment rel

Moller-Nielsen, E., N.O. Br 1997. Bioaerosol expo equipment, type of wa:

Morrison, D.C. and R.J. Ul Am. J. Pathol. 93: 527

Myatt, T.A., M.H. Kaufman, the airborne survival o Environ. Health 9: 55.

Nevalainen, A., J. Pastuszk collection characteristi

Newsome, A.L., T.M. Scott, a distinctive Legionell

Nielsen, K.F. 2003. Mycoto

Nielsen, K.F., S. Gravesen, mycotoxins on artificia

Pasanen, A.L., P. Kalliokosk work into farm homes.

Pasanen, A.L., H. Heinonensurfaces - an explanati

Pastuszka, J.S., K. T. Paw U, environments in Uppe

Peitzsch, M., M. Sulyok, M. ] R. Krska and L. Larss moisture damage in Fi

Pitkäranta, M. 2012. Molect damaged buildings. $\mathrm{Ph}$ 
Exner. 2002. Occurrence dust from damp indoor n. 2005. Large particles ation. J. Environ. Monit.

012. Seasonal variations midity, and air exchange

Jerritsen, J.C. de Jongste, $\rightarrow$ and mould components 33.

. Larsson, M. Jarosz, A. c dust, microorganisms, viron. Med. 16: 143-150. d S.A. Grinshpun. 2002. 68: 3522-3531.

itutions-part of a study. contamination of damp alth Perspect. 107 Suppl.

hmechel. 2006. Airborne

thaler. 2007. Assessment th. Atmos. Environ. 41:

ic fungi and bacteria. US

Stachybotrys chartarum uorogenic probe system.

Fahlbusch, R.W. Kinne, ren, endotoxin and fungi iol. 13: $152-160$.

azdi and J. Peccia. 2012. 7.

e. Science 308: 73.

diation in a building in a

Meklin. 2009. Microbial 407: 4673-4680.

Jetermination of bacterial riron. Monit. 12: 759-768. zsen, P.A. Nielsen and T. materials. Indoor Air 13:

ska, A. Hyvärinen and J. on with moisture damage ounds. Crit. Rev. Toxicol. domestic environments in
Larsson, L. 1994. Determination of microbial chemical markers by gas chromatography-mass spectrometry-potential for diagnosis and studies on metabolism in situ. Acta Pathol. Microbiol. Immunol. Scand. 102: 161-169.

Lehtonen, M., T. Reponen and A. Nevalainen. 1993. Everyday activities and variation of fungal spore concentration in indoor air. Int. Biodeter. Biodegrad. 31: 25-39.

Levetin, E., R. Shaughnessy, E. Fisher, B. Ligman, J. Harrison and T. Brennan. 1995. Indoor air quality in schools: exposure to fungal allergens. Aerobiologia 11:27-34.

Lin, X.J., T.A. Reponen, K. Willeke, S.A. Grinshpun, K.K. Foarde and D.S. Ensor. 1999. Long-term sampling of airborne bacteria and fungi into a non-evaporating liquid. Atmos. Environ. 33: 4291-4298.

Lioy, P.J., N.C.G. Freeman and J.R. Millette. 2002. Dust: a metric for use in residential and building exposure assessment and source characterization. Environ. Health Perspect. 110: 969-983.

Macher, J.M., F.Y. Huang and M. Flores. 1991. A two-year study of microbiological indoor air quality in a new apartment. Arch. Environ. Health 46:25-29.

Maki, T., M. Kakikawa, F. Kobayashi, M. Yamada, A. Matsuki, H. Hasegawa and Y. Iwasaka. 2013. Assessment of composition and origin of airborne bacteria in the troposphere over Japan. Atmos. Environ. 74: 73-82.

Matikainen, E. and A. Rantio-Lehtimäki. 1998. Semiquantitative and qualitative analysis of pre-seasonal airborne birch pollen allergens in different particle sazes-Background information for allergen reports. Grana 37: 293-297.

McDevitt, J.J., D.K. Milton, S.N. Rudnik and M.W. First. 2008. Inactivation of poxviruses by upper-room UVC light in a simulated hospital room environment. PLoS ONE 3(9): 1-9.

Meadow, J.F., A.E. Altrichter, S.W. Kembel, J. Kline, G. Mhuireach et al. 2013. Indoor airborne bacterial communities are influenced by ventilation, occupancy and outdoor air source. Indoor Air: DOI: 10.1111/ina.12047.

Meklin, T., T. Husman, A. Vepsäläinen, M. Vahteristo, J. Koivisto, J. Halla-aho, A. Hyvärinen, D. Moschandreas and A. Nevalainen. 2002. Indoor air microbes and respiratory symptoms of children in moisture damaged and reference schools. Indoor Air 12: 175-183.

Miguel, A.G., P.E. Taylor, J. House, M.M. Glovsky and R.C. Flagan. 2006. Meteorological influences on respirable fragment release from Chinese elm pollen. Aerosol Sci. Technol. 40: 690-696.

Moller-Nielsen, E., N.O. Breum, B. Herbert Nielsen, H. Wurtz, O. Melchior Poulsen and U. Midgaard. 1997. Bioaerosol exposure in waste collection: a comparative study on the significance of collection equipment, type of waste and seasonal variation. Ann. Occup. Hyg. 41: 325-344.

Morrison, D.C. and R.J. Ulevich. 1978. The effects of bacterial endotoxins on host mediating systems. Am. J. Pathol. 93: 527-617.

Myatt, T.A., M.H. Kaufman, J.G. Allen, D.L. Macintosh, M.P. Fabian and J.J. McDevitt. 2010. Modeling the airborne survival of influenza virus in a residential setting: the impacts of home humidification. Environ. Health 9: 55.

Nevalainen, A., J. Pastuszka, F. Liebhaber and K. Willeke. 1992. Performance of bioaerosol samplers: collection characteristics and sampler design consideration. Atmos. Environ. 26A: 531-540.

Newsome, A.L., T.M. Scott, R.F. Benson and B.S. Fields. 1998. Isolation of an amoeba naturally harboring a distinctive Legionella species. Appl. Environ. Microbiol. 64: 1688-1693.

Nielsen, K.F. 2003. Mycotoxin production by indoor molds. Fungal Genet. Biol. 39: 103-117.

Nielsen, K.F., S. Gravesen, P.A. Nielsen, B. Andersen, U. Thrane and J.C. Frisvad. 1999. Production of mycotoxins on artificially and naturally infested building materials. Mycopathologia 145: 43-56.

Pasanen, A.L., P. Kalliokoski, P. Pasanen, T. Salmi and A. Tossavainen. 1989. Fungi carried from farmers' work into farm homes. Am. Int. Hyg. Assoc. J. 50: 631-633.

Pasanen, A.L., H. Heinonen-Tanski, P. Kalliokoski and M.J. Jantunen. 1991. Fungal microcolonies on indoor surfaces-an explanation for the base level fungal counts in indoor air. Atmos. Environ. 26B: 117-120.

Pastuszka, J.S., K.T. Paw U, D.O. Lis, A. Wlazło and K. Ulfig. 2000. Bacterial and fungal aerosol in indoor environments in Upper Silesia, Poland. Atmos. Environ. 34: 3833-3842.

Peitzsch, M., M. Sulyok, M. Täubel, V. Vishwanath, E. Krop, A. Borrás-Santos, A. Hyvärinen, A. Nevalainen, R. Krska and L. Larsson. 2012. Microbial secondary metabolites in school buildings inspected for moisture damage in Finland, The Netherlands and Spain. J. Environ. Monit. 14: 2044-2053.

Pitkäranta, M. 2012. Molecular profiling of indoor microbial communities in moisture damaged and nondamaged buildings. PhD Thesis, University of Helsinki, Finland, 2012. 
Pitkäranta, M., T. Meklin, A. Hyvärinen, L. Paulin, P. Auvinen and A. Nevalainen. 2008. Analysis of fungal flora in indoor dust by ribosomal DNA sequence analysis, quantitative PCR and culture. Appl. Environ. Microbiol. 74: 233-244.

Polizzi, V., B. Delmulle, A. Adams, A. Moretti, A. Susca, A.M. Picco, Y. Rosseel, R. Kindt, J. Van Bocxlaer, N. De Kimpe, C. Van Peteghem and S. De Saeger. 2009. JEM Spotlight: Fungi, mycotoxins and microbial volatile organic compounds in mouldy interiors from water-damaged buildings. J. Environ. Monit. 11: 1849-1858.

Polymenakou, P.N. 2012. Atmosphere: a source of pathogenic or beneficial microbes? Atmosphere 3: 87-102. Prospero, J.M., E. Blades and G. Mathison. 2005. Interhemispheric transport of viable fungi and bacteria from Africa to the Caribbean with soil dust. Aerobiologia 21: 1-19.

Rappe, M.S. and S.J. Giovannoni. 2003. The uncultured microbial majority. Ann. Rev. Microbiol. 57: 369-394.

Rautiala, S., T. Reponen, A. Hyvärinen, A. Nevalainen, T. Husman, A. Vehviläinen and P. Kalliokoski. 1996. Exposure to airborne microbes during the repair of moldy buildings. Am. Ind. Hyg. Assoc. J. 57: 279-284.

Rautiala, S., J. Kangas, K. Louhelainen and M. Reiman. 2003. Farmer's exposure to airborne microorganisms in composting swine confinement buildings. Am. Ind. Hyg. Assoc. J. 64: 673-677.

Ren, P., T.M. Jankun and B.P. Leaderer. 1999. Comparisons of seasonal fungal prevalence in indoor and outdoor air and in house dusts of dwellings in one Northeast American county. J. Exposure Anal. Environ. Epidemiol. 9: 560-568.

Reponen, T., A. Nevalainen, M. Jantunen, M. Pellikka and P. Kalliokoski. 1992. Normal range criteria for indoor bacteria and fungal spores in a subarctic climate. Indoor Air 2: 26-31.

Reponen, T., K. Willeke, S. Grinshpun and A. Nevalainen. 2011. Biological particle sampling. pp. 549-570. In: P. Kulkarni, P.A. Baron and K. Willeke [eds.]. Aerosol Measurement, Principles, Techniques and Applications, 3rd Ed. John Wiley \& Sons, Inc., Holbroken, New Jersey, USA.

Rintala, H. and A. Nevalainen. 2006. Quantitative measurement of streptomycetes using real-time PCR. J. Environ. Monit. 8: 745-749.

Rintala, H., A. Hyvärinen, L. Paulin and A. Nevalainen. 2004. Detection of streptomycetes in house dustcomparison of culture and PCR methods. Indoor Air 14: 112-119.

Rintala, H., M. Pitkäranta and M. Täubel. 2012. Microbial communities associated with house dust. In: Allen I. Laskin, S. Sariaslani and G.M. Gadd [eds]. Adv. Appl. Microbiol. 78: 75-120.

Rodriquez-Zaragoza, S. 1994. Ecology of free-living amoebae. Crit. Rev. Microbiol. 20: 225-241.

Saraf, A., L. Larsson, H. Burge and D. Milton. 1997. Quantification of ergosterol and 3-hydroxy fatty acids in settled house dust by gas chromatography-mass spectrometry: comparison with fungal culture and determination of endotoxin by a Limulis amebocyte lysate assay. Appl. Environ. Microbiol. 63(7): 2554-9.

Sebastian, A. and L. Larsson. 2003. Characterization of the microbial community in indoor environments: a chemical-analytical approach. Appl. Environ. Microbiol. 69(6): 3103-3109.

Shorter, C. 2012. Fungi in New Zealand homes: Measurement, aerosolization \& association with children's health. $\mathrm{PhD}$ thesis, University of Otago, New Zealand.

Smith, D.J., D.A. Jaffe, M.N. Birmele, D.W. Griffin, A.C. Schuerger, J. Hee and M.S. Roberts. 2012. Free tropospheric transport of microorganisms from Asia to North America. Micr. Ecol. 64: 973-985.

Starr, M.P., H. Stolp, H.G. Trüper, A. Balows and H.G. Schlegel [eds.]. 1981. The Prokaryotes, A Handbook on Habitats, Isolation and Identification of Bacteria. Spinger-Verlag, Berlin, Heidelberg, New York.

Täubel, M., H. Rintala, M. Pitkäranta, L. Paulin, S. Laitinen, J. Pekkanen, A. Hyvärinen and A. Nevalainen. 2009. The occupant as a source of house dust bacteria. J. Allergy Clin. Immunol. 124(4): 834-840.

Täubel, M., M. Sulyok, V. Vishwanath, E. Bloom, M. Turunen, K. Järvi, E. Kauhanen, R. Krska, A. Hyvärinen, L. Larsson and A. Nevalainen. 2011. Co-occurrence of toxic bacterial and fungal secondary metabolites in moisture-damaged indoor environments. Indoor Air 21: 368-375.

Toivola, M., S. Alm, T. Reponen, S. Kolari and A. Nevalainen. 2002. Personal exposures and microenvironmental concentrations of particles and bioaerosols. J. Environ. Monit. 4: 166-174.

Torvinen, E., P. Torkko and H. Rintala. 2010. Real-time PCR detection of environmental mycobacteria in house dust. J. Microbiol. Methods 82: 78-84.

Tsapko, V.G., A.J. Chudnovets, M.J. Sterenbogen, V.V. Papach, J. Dutkiewicz, C. Skórska, E. KrysinskaTraczyk and M. Golec. 2011. Exposure to bioaerosols in the selected agricultural facilities of the Ukraine and Poland—a review. Ann. Agric. Environ. Med. 18: 19-27. 
nen. 2008. Analysis of PCR and culture. Appl.

. Kindt, J. Van Bocxlaer, Fungi, mycotoxins and ed buildings. J. Environ.

Atmosphere 3: 87-102. iable fungi and bacteria

in. Rev. Microbiol. 57:

nen and P. Kalliokoski. Am. Ind. Hyg. Assoc. J.

lirborne microorganisms 3-677.

revalence in indoor and unty. J. Exposure Anal.

Jormal range criteria for L.

: sampling. pp. 549-570. nciples, Techniques and A.

es using real-time PCR. mycetes in house dustted with house dust. In: 8: $75-120$.

iol. 20: 225-241.

nd 3-hydroxy fatty acids I with fungal culture and viron. Microbiol. 63(7):

in indoor environments: 9.

sociation with children's

1.S. Roberts. 2012. Free r. Ecol. 64: 973-985.

rokaryotes, A Handbook Heidelberg, New York. inen and $A$. Nevalainen. unol. 124(4): 834-840. sauhanen, R. Krska, A. ial and fungal secondary 375 .

rsonal exposures and Monit. 4: 166-174. mental mycobacteria in Skórska, E. Krysinskacultural facilities of the
WHO. 2009. WHO Guidelines for Indoor Air Quality: Dampness and Mould. World Health Organization, Copenhagen, Denmark, 228 pp.

Yamamoto, N., M. Kimura, H. Matsuki and Y. Yanagisawa. 2010. Optimization of a real-time PCR assay to quantitate airborne fungi collected on a gelatin filter. J. Biosci. Bioeng. 109: 83-88.

Yang, W. and L.C. Marr. 2011. Dynamics of airborne influenza A viruses indoors and dependence on humidity. PLoS ONE 6(\&): e21481.

Yao, M.S. and G. Mainelis. 2006. Utilization of natural electrical charges on airborne microorganisms for their collection by electrostatic means. J. Aerosol Sci. 37: 513-527.

Yli-Pirilä, T. 2009. Amoebae in moisture-damaged buildings. $\mathrm{PhD}$ dissertation. National Institute for Health and Welfare, Kuopio, Finland.

Yli-Pirilä, T., J. Kusnetsov, M.-R. Hirvonen, M. Seuri and A. Nevalainen. 2006. Effects of amoebae on the growth of microbes isolated from moisture-damaged buildings. Can. J. Microbiol. 52: 383-390.

Yli-Pirilä, T., K. Huttunen, A. Nevalainen, M. Seuri and M.-R. Hirvonen. 2007. Effects of co-culture of amoebae with indoor microbes on their cytotoxic and proinflammatory potential. Environ. Toxicol. 22: 357-367.

Yossifova, Y.Y., T. Reponen, D.I. Bernstein, L. Levin, H. Kalra, P. Campo, M. Villareal, J. Lockey, G.K. Hershey and G. LeMasters. 2007. House dust (1-3)-beta-D-glucan and wheezing in infants. Allergy 62: 504-513. 


\section{Synergic Influence of Gaseous, Particulate, and Biological Pollutants on Human Health}

Editor

Jozef Stefan Pastuszka

Associate Professor of Environmental Engineering

Head of the Chair of Air Protection

Silesian University of Technology

Gliwice

Poland

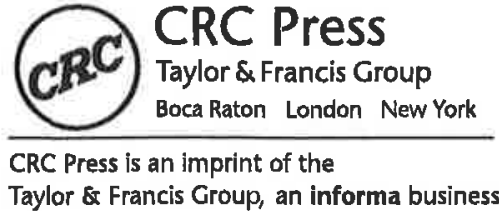

A SCIENCE PUBLISHERS BOOK 
Cover illustrations reproduced by kind courtesy of Dr. Józef Pastuszka (editor of the book) and Prof. Ewa Talik (University of Silesia in Katowice, Poland).

CRC Press

Taylor \& Francis Group

6000 Broken Sound Parkway NW, Suite 300

Boca Raton, FL 334:87-2742

(C) 2016 by Taylor \& Francis Group, LLC

CRC Press is an imprint of Taylor \& Francis Group, an Informa business

No claim to original U.S. Government works

Printed on acid-free paper

Version Date: 20150805

International Standard Book Number-13: 978-1-4987-1511-9 (Hardback)

This book contains information obtained from authentic and highly regarded sources. Reasonable efforts have been made to publish reliable data and information, but the author and publisher cannot assume responsibility for the validity of all materials or the consequences of their use. The authors and publishers have attempted to trace the copyright holders of all material reproduced in this publication and apologize to copyright holders if permission to publish in this form has not been obtained. If any copyright material has not been acknowledged please write and let us know so we may rectify in any future reprint.

Except as permitted under U.S. Copyright Law, no part of this book may be reprinted, reproduced, transmitted, or utilized in any form by any electronic, mechanical, or other means, now known or hereafter invented, including photocopying, microfilming, and recording, or in any information storage or retrieval system, without written permission from the publishers.

For permission to photocopy or use material electronically from this work, please access www.copyright. com (http://www.copyright.com/) or contact the Copyright Clearance Center, Inc. (CCC), 222 Rosewood Drive, Danvers, MA 01923, 978-750-8400. CCC is a not-for-profit organization that provides licenses and registration for a variety of users. For organizations that have been granted a photocopy license by the CCC, a separate system of payment has been arranged.

Trademark Notice: Product or corporate names may be trademarks or registered trademarks, and are used only for identification and explanation without intent to infringe.

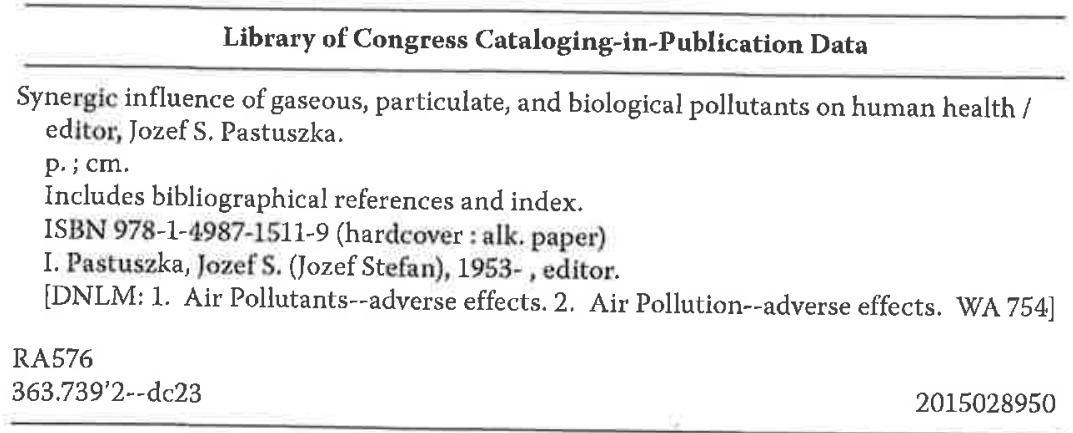

Visit the Taylor \& Francis Web site at

http://www.taylorandfrancis.com

and the CRC Press Web site at

http://www.crcpress.com

Airborne substc aerosols includi health. This boc pollutants, their hazards, as well and attributes of Many of the rece and the handling 